\title{
EMISE SKLENÍKOVÝCH PLYNŮ PŘI VÝROBĚ VYBRANÝCH KONTAKTNÍCH TEPELNĚ- IZOLAČNÍCH MATERIÁLŮ
}

\author{
EMISSIONS RELEASED DURING THE PRODUCTION OF SELECTED \\ CONTACT THERMAL INSULATION MATERIALS
}

\begin{abstract}
Dominik Horenský*,1
*xahorensky@vutbr.cz

${ }^{1}$ Fakulta architektury VUT v Brně, Poříčí 5, 63900 Brno

Abstrakt

Tématem práce je studium vlivu vybraných tepelně-izolačních materiálů na klimatickou změnu. Konkrétně jsou v článku komparována množství $\mathrm{CO}_{2}$ a $\mathrm{SO}_{2}$ vypouštěných do ovzduší při výrobě těchto materiálů. Materiály jsou voleny pro kontaktní zateplovací systémy. Vstupní data jsou z databází EPD (Environmentální deklarace o produktu), které splňují ISO 14025. Cílem je představit výrobní fázi životního cyklu stavebních materiálů a důležitost jejich výběru pro snižování emisí. Z analyzovaných materiálů dopadlo nejlépe konopí, které dosáhlo negativní produkce $\mathrm{CO}_{2}$ a nejnižší produkce $\mathrm{SO}_{2}$ ze všech, a to i přes jeho větší tloušt'ku. Výstupy lze využít pro navazující výzkum díky vstupním datům splňující ISO standard.
\end{abstract}

\section{Klíčová slova}

Analýza životního cyklu, tepelně-izolační materiály, klimatická změna, EPD.

\begin{abstract}
The topic of the thesis is the study of the influence of selected thermal insulation materials on climate change. Specifically, the amounts of $\mathrm{CO}_{2}$ and $\mathrm{SO}_{2}$ emitted into the atmosphere during the production of these materials are compared. The materials are chosen for contact insulation systems. The input data are from EPD (Environmental Product Declaration) databases that comply with ISO 14025. The aim is to present the production phase of the life cycle of building materials and the importance of their selection for emission reduction. Of the materials analysed, hemp performed best, achieving negative $\mathrm{CO}_{2}$ production and the lowest $\mathrm{SO}_{2}$ production of all, despite its greater thickness. The results can be used for further research due to the input data meeting the ISO standard.
\end{abstract}

\section{Key words}

Life cycle analysis, thermal insulation materials, climate change, EPD.

\section{1 ÚVOD}

Zmírnění negativních vlivů na klima je celosvětově aktuálním tématem. Jedním z dopadů vlivu člověka je klimatická změna a stavebnictví k ní přispívá významnou měrou [1]. Analýzou dat a kvantifikací jednotlivých fází ve stavebnictví, z hlediska nadměrné emitace plynů ovlivňující klima, je možné dohledat hlavní činitele přispívající k této klimatické změně a optimalizovat je. Rozšířenou metodou napříč odvětvími je analýza životního cyklu (Life Cycle Assesment, dále LCA), která se může aplikovat na všechny produkty, takže i na stavební materiály. Současná platná evropská legislativa klade důraz na provozní fázi objektů, tzn. jakou má objekt spotřebu energie a jestli je zdroj energie v dostatečné míře obnovitelný. Tyto podmínky kladou mj. důraz na větší tloušt'ku tepelně-izolačního materiálu, což znamená menší tepelné ztráty objektu [2], [3]. Se snižujícím se vlivem provozní fáze na celkovou produkci plynů ovlivňujících klima, roste důležitost výrobní fáze stavebních materiálů, ze kterých je objekt postaven [4].

V článku jsou analyzovány a komparovány výrobní fáze vybraných tepelně-izolačních materiálů s ohledem na legislativní požadavky součinitele prostupu tepla. Ostatní prvky souvrství, jako je nosná část a př́padné omítky a obklady jsou uvažovány jako identické pro všechny posuzované stavební materiály a nejsou proto v práci obsaženy. 
Fáze konce životního cyklu a ani možnosti znovu využití stavebního materiálu nejsou v článku řešeny. Stejně tak není řešena problematika obnovitelných zdrojů energie, protože neovlivní výsledky komparace.

\section{POPIS SOUČASNÉHO STAVU}

V České republice je od roku 2020 ze zákona povinné stavět veškeré novostavby ve standardu s téměř nulovou spotřebou energie, což klade zvýšené požadavky na obálku budovy a kvalitu tepelných izolací, a tím roste jejich tloušt'ka v souvrství. Snížení energetické náročnosti budov v době jejich užívání je patrné z Obr. 1.

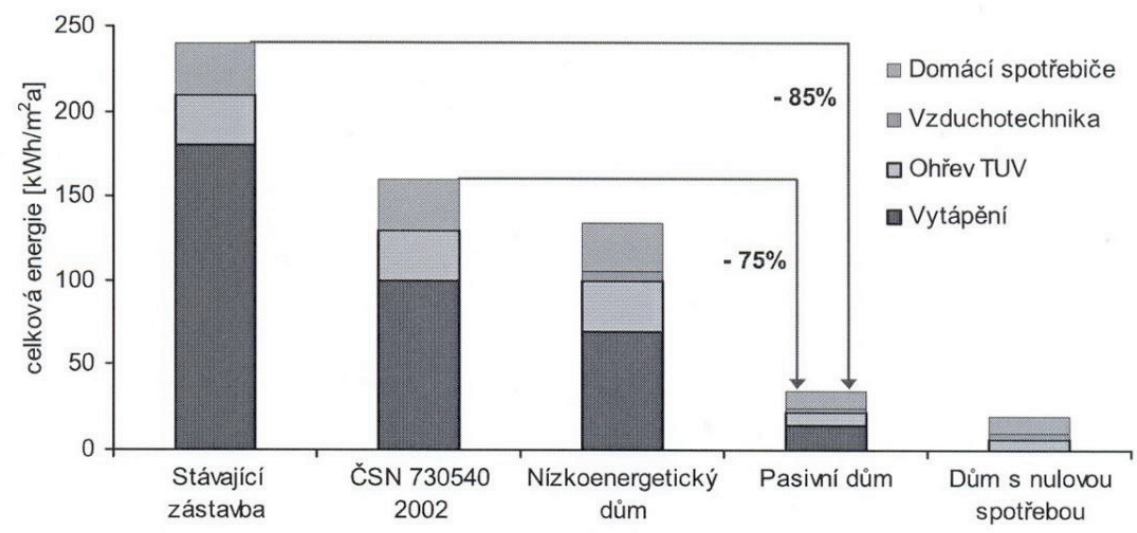

Obr. 1 Znázornění celkové spotřeby energie provozní fáze objektů s různou kategorizací energetické náročnosti [5].

Větší tloušt'ka obálky budovy, především tepelně-izolačních materiálů, zvyšuje i produkci emisí. Na Obr. 2 je patrný rostoucí trend potenciálu globálního oteplování (GWP) definovaný jednotkou produkce $\mathrm{kg} \mathrm{CO}_{2} \mathrm{ekv} . / \mathrm{m}^{2}$. V praxi se jen málo počítá s energií a látkami, které jsou spjaté s výrobou daných stavebních hmot. Jde především o produkci skleníkových plynů, které v celosvětovém měřítku nejsou zanedbatelné [6]. Optimalizací staveb již v projektové fázi a probádání všech materiálových možností lze stavět environmentálně šetrnější objekty, a to nejen z hlediska snížené spotřeby na provoz objektu, ale i redukci již v provozní fázi stavebních materiálů.

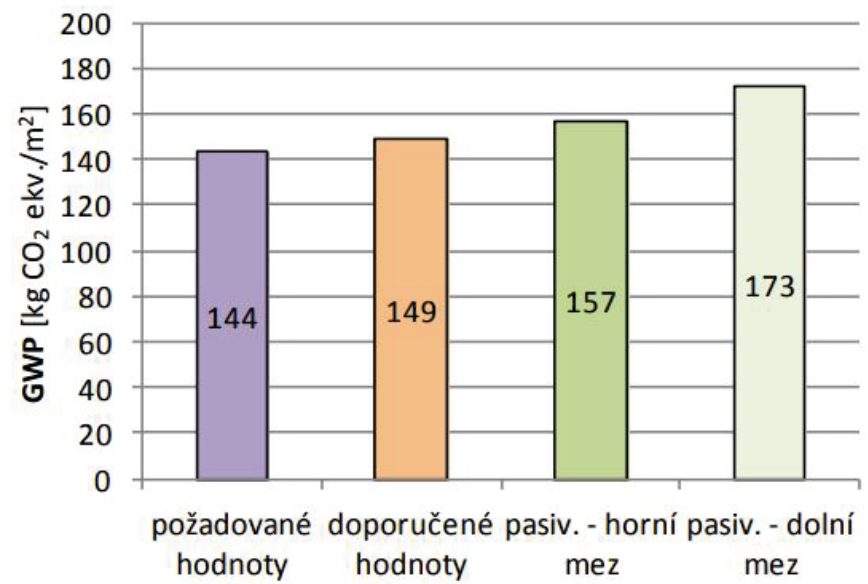

Obr. 2 Růst průměrného GWP (ze všech konstrukcí budovy) v závislosti na tepelně-izolační úrovni obálky [7]. 


\section{Hodnocení životního cyklu (LCA)}

Pro analýzu množství uvolněných emisí tepelně-izolačních materiálů je využita metodika hodnocení životního cyklu LCA. Tato metodika člení produkt do několika fází, Obr. 1. Fáze životního cyklu obsahují dílčí kategorie, které jsou v rámci této metodiky analyzovány a kvantifikovány pro každý produkt.

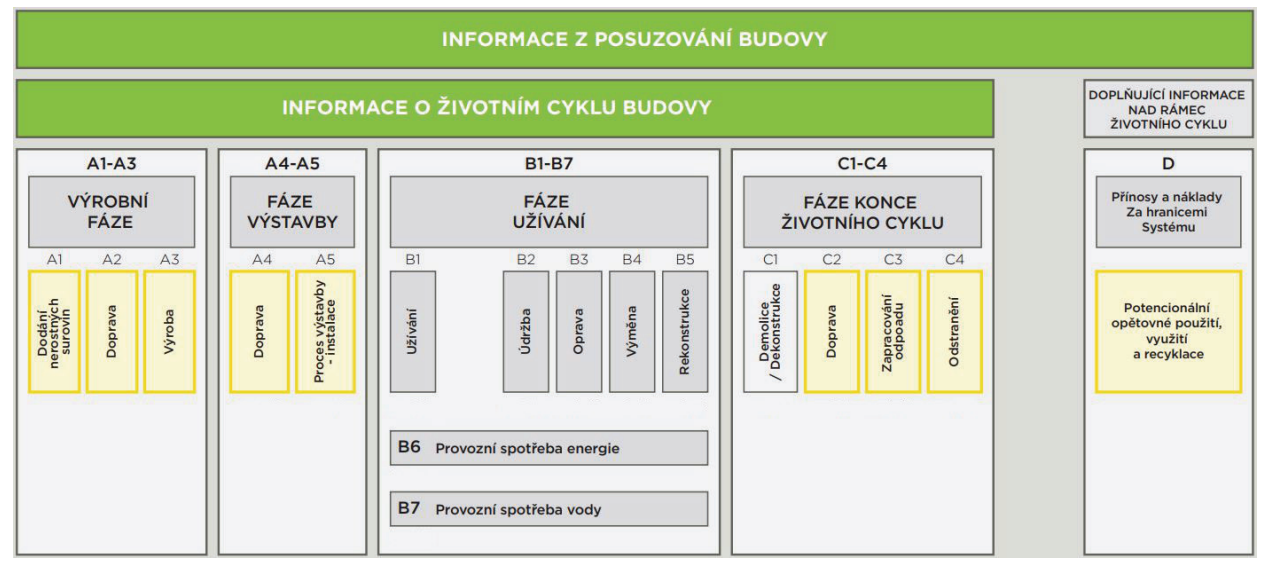

Obr. 3 Schéma rozdělení fází životního cyklu [8].

Výsledkem analýzy je velké množství dat znázorňující celý životní cyklus produktu. Získání přesných dat je ovšem složité a také jejich interpretace se může lišit, což dává prostor k odchylkám při užívání více zdrojů dat (databází).

Možností, jak tento problém řešit, je využití českých technických normách (ČSN), konkrétně se jedná o soubor norem ČSN ISO 14020. Dủležitou normou ze souboru je ČSN ISO 14025-2:2011 Environmentální značky a prohlášení - Environmentální prohlášení typu III - Zásady a postupy (ekvivalentem je standard ISO 14020 v anglickém jazyce). Norma stanovuje zásady a postupy pro vytváření programů environmentálních prohlášení a je založena na nezávislém ověření dat LCA třetí stranou [8], [9].

V praxi je výstupem programu environmentální prohlášení o produktu (EPD), často nazývané také jako Ekolist, ekoprofil nebo environmentální profil produktu. Pokud budou dodrženy zásady zmíněného souboru norem, pak je možné využívat všech zdrojů dat a komparovat je. Veškerá data použitá pro tuto komparaci v rámci metodiky LCA odpovídají standardu ČSN ISO 14025-2:2011 [10].

\section{Parametry environmentálních dopadů}

Posuzované parametry jsou vybrány z užitých norem. Konkrétně se v kategorii environmentálních dopadů jedná o potenciál globálního oteplování (GWP) a potenciál acidifikace půdy a vody (AP). Potenciál globálního oteplování vyjadřuje vliv na globální oteplování z emisí jedné jednotky referenčního kg oxidu uhličitého. Potenciál acidifikace půdy a vody vyjadřuje míru acidifikace, což je především negativní dopad na ekosystém, jednotkou jsou emise jedné jednotky referenčního kg oxidu siřičitého [9]. Kromě zmíněných parametrů se v EPD vyskytují i další parametry, jako např. potenciál úbytku stratosférické ozónové vrstvy, potenciál eutrofizace nebo potenciál tvorby př́zemního ozónu. Ty nejsou pro rozsah práce posuzovány. Jednotky $\mathrm{CO}_{2}$ a $\mathrm{SO}_{2}$ jsou pro komparaci vybrány, jelikož je emitování těchto plynů úzce spojeno se spalováním fosilních paliv při výrobě elektřiny a tepla, což ovlivňuje velkou část stavebního sektoru.

Problematikou komparace množství jednotek posuzovaných parametrů se zabývají i další práce. [11], [12], [13], [14]. Podrobněji jsou tepelně-izolační materiály a jejich tloušt'ky v závislosti na GWP a AP posuzovány v publikaci [15], která komparuje jak hodnoty $\mathrm{CO}_{2}$ a $\mathrm{SO}_{2}$, tak ceny izolanti̊ s ohledem na celý životní cyklus budovy.

\section{METODIKA}

Materiály vybrané pro analýzu jsou určeny pro kontaktní zateplovací systémy (ETICS) a data jsou čerpána z ověřených EPD konkrétních produktů [16], [17], [18], [19]. Vybrané jsou tyto materiály: 
- Expandovaný polystyrén,

- Minerální vlna,

- Fenolická pěna,

- Konopí.

Každý z těchto materiálů má odlišné vlastnosti, v rámci této analýzy je podstatný součinitel tepelné vodivosti znázorněný v Tab. 1. Tento součinitel je zásadní pro tloušt'ku materiálu, který by byl v systému ETICS instalován.

Tab. 1 Parametry analyzovaných tepelně-izolačních materiálů.

\begin{tabular}{ccccc}
\hline & $\begin{array}{c}\text { Expandovaný } \\
\text { polystyrén }\end{array}$ & $\begin{array}{c}\text { Minerální } \\
\text { vlna }\end{array}$ & Fenolická pěna & Konopí \\
\hline $\begin{array}{c}\text { Součinitel } \\
\text { tepelné vodivosti } \\
\boldsymbol{\lambda}_{\mathbf{D}}[\mathbf{W} /(\mathbf{m} \cdot \mathbf{K})]\end{array}$ & 0,031 & 0,035 & 0,021 & 0,04 \\
\hline
\end{tabular}

Tloušt'ka materiálu je odvozena z normy ČSN 73 0540-2:2011, která stanovuje hodnoty součinitele prostupu tepla U konstrukcemi. Pro vnějši stěnu je zvolena hodnota $\mathrm{U}=0,17 \mathrm{~W} /\left(\mathrm{m}^{2} \cdot \mathrm{K}\right)$. Tloušt'ky materiálu jsou vypočteny ze součinitele prostupu tepla a zaokrouhleny na celé jednotky $\mathrm{cm}$. S materiály včetně jejich navržených dimenzí je počítáno v další kapitole.

Tab. 2 Navržené tloušt'ky tepelně-izolačních materiálů.

\begin{tabular}{ccccc}
\hline & $\begin{array}{c}\text { Expandovaný } \\
\text { polystyrén }\end{array}$ & $\begin{array}{c}\text { Minerální } \\
\text { vlna }\end{array}$ & Fenolická pěna & Konopí \\
\hline $\begin{array}{c}\text { Navržená tloušt'ka } \\
{[\mathrm{mm}]}\end{array}$ & 180 & 200 & 120 & 230 \\
\hline
\end{tabular}

\section{VÝSLEDKY}

Interpolací tabulkových hodnot analyzovaných EPD na základě tloušt'ky materiálu jsou zjištěny hodnoty v Tab. 3. Expandovaný polystyrén, minerální vlna a fenolická pěna vykazují hodnoty od 8,820 do $13,588 \mathrm{~kg} \mathrm{CO} 2 \mathrm{ekv} . / \mathrm{m}^{2}$. Konopí během své výroby vyprodukuje nejnižší množství $\mathrm{CO}_{2}$, navíc během růstu na sebe váže uhlík [8] a odebere z ovzduší 10,120 kg CO $\mathrm{CO}_{2} \mathrm{ek} . / \mathrm{m}^{2}$. Fosilní potenciál globálního oteplování je u konopí i tak nejnižší z hodnocených. Potenciál acidifikace půdy a vody má nejvyšší minerální vlna, nejlepší výsledky dosáhl tepelně-izolační materiál z konopí.

Tab. 3 Emise $\mathrm{CO}_{2}$ a $\mathrm{SO}_{2}$ vyprodukované ve výrobní fázi (A1-A3) vybraných tepelně-izolačních fasádních desek v navržené tloušt'ce.

\begin{tabular}{cccccc}
\hline & Jednotka & $\begin{array}{c}\text { Expandovaný } \\
\text { polystyrén }\end{array}$ & $\begin{array}{c}\text { Minerální } \\
\text { vlna }\end{array}$ & $\begin{array}{c}\text { Fenolická } \\
\text { pěna }\end{array}$ & Konopí \\
\hline $\begin{array}{c}\text { Potenciál globálního } \\
\text { oteplování - fosilní } \\
\text { (GWP) }\end{array}$ & $\begin{array}{c}\mathrm{kg} \mathrm{CO} \\
\mathrm{ekv} . / \mathrm{m} 2\end{array}$ & 8,820 & 13,588 & 9,252 & 3,082 \\
$\begin{array}{c}\text { Potenciál globálního } \\
\text { oteplování - biogenní } \\
\text { (GWP biogenic) }\end{array}$ & $\begin{array}{c}\mathrm{kg} \mathrm{CO} \\
\mathrm{ekv} . / \mathrm{m} 2\end{array}$ & - & - & - & $-10,120$ \\
$\begin{array}{c}\text { Potenciál acidifikace } \\
\text { půdy a vody (AP) }\end{array}$ & $\begin{array}{c}\mathrm{kg} \mathrm{SO} \\
\mathrm{ekv} . / \mathrm{m} 2\end{array}$ & $8,280 \cdot 10^{-3}$ & $9,632 \cdot 10^{-2}$ & $1,728 \cdot 10^{-2}$ & $7,912 \cdot 10^{-3}$ \\
\hline
\end{tabular}


Data z tabulky jsou pro přehlednost znázorněna graficky v Obr. 4 a Obr. 5. Fosilní i biogenní potenciály globálního oteplování jsou sečteny.

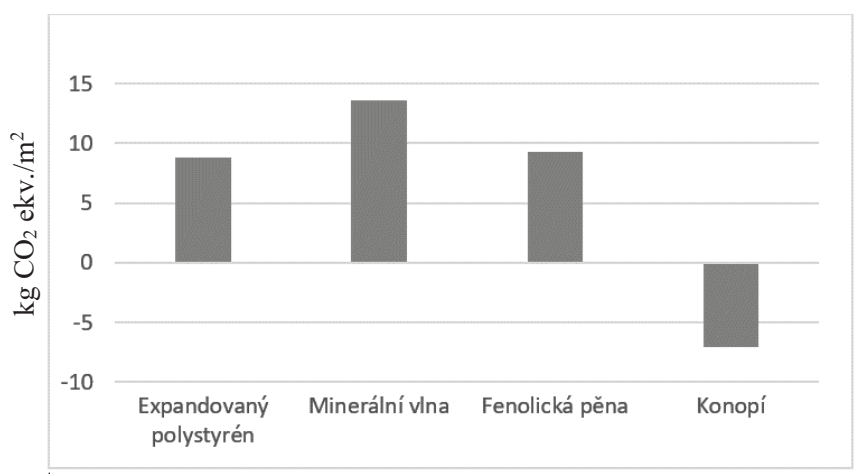

Obr. 3 Výsledný potenciál globálního oteplování (GWP).

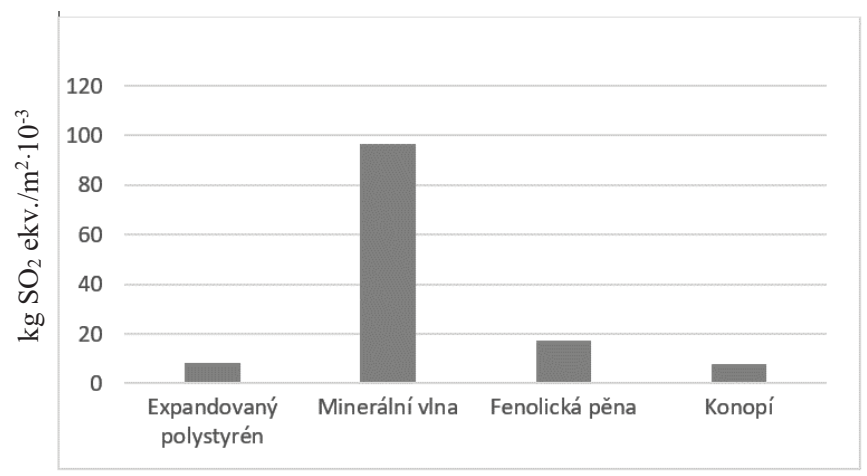

Obr. 4 Výsledný potenciál acidifikace půdy a vody (AP).

\section{ZÁVĚR}

Komparovaná data poukazují na rozdíly v množství emisí $\mathrm{CO}_{2}$ a $\mathrm{SO}_{2}$ uvolněných ve výrobní fázi produktu. Z výsledných grafů je zjevné, že volbou vhodného tepelně-izolačního materiálu je možné docílit snížení emisí v ovzduší už v jeho výrobní fázi. Jako vhodný je v tomto případě prrírodní materiál - konopí. Tento materiál pohltí $\mathrm{z}$ ovzduší přes $7 \mathrm{~kg} \mathrm{CO} 2 \mathrm{ekv} . / \mathrm{m}^{2}$ při tepelném odporu $5,75 \mathrm{~K} \cdot \mathrm{m}^{2} \cdot \mathrm{W}^{-1}$. Ostatní materiály př́i výrobě naopak emise generují.

Práce s daty splňující standard ISO 14025 (ČSN ISO 14025-2:2011) zajišt’uje kompatibilitu výsledků s ostatními projekty i v mezinárodním prostředí, které tento standard také splňují. Jednotné zásady a postupy pro kvantifikaci životního cyklu budov a stavebních materiálů jsou nezbytné pro udržitelnou výstavbu. Zhodnocení současných pasivních domů i z ostatních hledisek, jaké jsou řešeny v článku, může být ve větším měřítku např. formou prŕpadových studií stávajících objektů a analýzou veškerých vstupů a výstupů. Tímto způsobem lze posoudit skutečnou environmentální zátěž objektu po celý jeho životní cyklus.

\section{Poděkování}

Článek vznikl za podpory Juniorského specifického výzkumu s registračním číslem FA-J-21-7300.

\section{Použité zdroje}

[1] WMO [World Meteorological Organization]. WMO Statement on the State of the Global Climate in 2019. ŠVÝCARSKO, WHO, 2020, ISBN 978-92-62-11248-5. 
[2] VONKA, Martin. A19 - Úvod do problematiky environmentální hodnocení a certifikace budov dle principů trvale udržitelné výstavby. Národní stavební centrum, 2012. ISBN 978-80-87665-18-3.

[3] ČSN 73 0540-2 Tepelná ochrana budov:část 2: Požadavky. Praha: Český normalizační institut, 2011.

[4] CHYBÍK, Josef. Energeticky úsporná výstavba. BRNO, Akademické nakladatelství CERM, 2012, ISBN 978-80-7204-813-7.

[5] Passivhaus Institut, Passivhaus Projektierung Paket - PHPP 2004, Darmstadt - Dr. Wolfgang Feista.

[6] Svázané hodnoty energie a emisí CO2 v systémech TZB [online]. [cit.2021-10-25]. Dostupné z: http://www.tzb-info.cz/3250-svazane-hodnoty-energie-a-emisi-co2-vsysteech-tzb.

[7] RYKLOVÁ Pavla. Environmentálně-energetická optimalizace obálky budovy bytového domu. Dostupný na WWW: https:/dspace.cvut.cz/bitstream/handle/10467/74362/F1-DP-2018-Ryklova-PavlaDP PR.pdf?sequence $=-1$ \&isAllowed $=\mathrm{y}$.

[8] ČSN EN 15804+A1ČSN EN 15804+A1 (730912) Udržitelnost staveb - Environmentální prohlášení o produktu - Základní pravidla pro produktovou kategorii stavebních produktů.

[9] Standards catalogue. Dostupné z: www.iso.org [online]. [cit.2021-10-25]. Dostupné z: www.iso.org

[10] KIERULF, Bjørn. Ekologická výstavba EPD. BRNO, Centrum pasivního domu, 2008, ISBN 978-80-2542848-1.

[11] PORHINČĂK, M.; EŠTOKOVÁ, Adriana. Evaluation of environmental performance of building materials-study of 3 residential houses in Slovak Republic. Central Europe Towards Sustainable Building, 2013.

[12] TETTEY, Uniben Yao Ayikoe; DODOO, Ambrose; GUSTAVSSON, Leif. Effects of different insulation materials on primary energy and $\mathrm{CO} 2$ emission of a multi-storey residential building. Energy and Buildings, 2014.

[13] JI, Changyoon; HONG, Taehoon; PARK, Hyo Seon. Comparative analysis of decision-making methods for integrating cost and $\mathrm{CO} 2$ emission-focus on building structural design-. Energy and Buildings, 2014.

[14] BUCHANAN, Andrew H.; LEVINE, S. Bry. Wood-based building materials and atmospheric carbon emissions. Environmental Science \& Policy, 1999.

[15] OZEL, Meral. Cost analysis for optimum thicknesses and environmental impacts of different insulation materials. Energy and Buildings, 2012.

[16] EPD Environmentální prohlášení o produktu.pdf [online]. [cit. 2021-10-25]. Dostupné z: https://www.cenia.cz/wp-content/uploads/2019/09/ISOVER-EPS-GREYWALL-GREYWALLPLUS.pdf

[17] EPD Environmentální prohlášení o produktu.pdf [online]. [cit. 2021-10-25]. Dostupné z: https://www.cenia.cz/wp-content/uploads/2020/12/EPD-ISOVER-TF-Thermo-CZ.pdf

[18] EPD Environmentální prohlášení o produktu.pdf [online]. [cit. 2021-10-25]. Dostupné z: http://test7.kingspan.com/getattachment/Miljo-och-hallbarhet/Kooltherm-K5--EPD_KSI_20130227_IAC1_EN.PDF.aspx

[19] EPD Environmentální prohlášení o produktu.pdf [online]. [cit. 2021-10-25]. Dostupné z: https://portal.environdec.com/api/api/v1/EPDLibrary/Files/25ef1 fda-8719-42fe-b33ca71f9fcde9b9/Data 